To cite: D McQuoid-Mason 'Challenges when drafting legal aid legislation to ensure access to justice in African and other developing countries with small numbers of lawyers: Overcoming obstacles to including the use of non-lawyers to assist persons in conflict with the law ' (2018) 18 African Human Rights Law Journal 486-507

http://dx.doi.org/10.17159/1996-2096/2018/v18n2a3

\title{
Challenges when drafting legal aid legislation to ensure access to justice in African and other developing countries with small numbers of lawyers: Overcoming obstacles to including the use of non-lawyers to assist persons in conflict with the law
}

David McQuoid-Mason*

President of the Commonwealth Legal Education Association; Professor of Law, Centre for Socio-Legal Studies, University of KwaZulu-Natal, Durban, South Africa

\section{Summary}

The United Nations Principles and Guidelines on Access to Legal Aid in Criminal Justice Systems, the United Nations Commission on Legal Empowerment of the Poor Report, the United Nations Office of Drugs and Crime Early Access Handbook and the United Nations Model Legal Aid in Criminal Proceedings Law can all be used when drafting legal aid legislation to ensure the accessibility, effectiveness, sustainability and credibility of legal aid services. Challenges to referring to the UN Principles and Guidelines and other relevant UN documents when drafting legal aid legislation in developing countries - particularly in Africa - with small numbers of lawyers arise because of opposition by the organised legal profession and the judiciary. They object to the use of the assistance of

BComm (Natal) LLB (Natal) LLM (London) PhD (Natal); MCQUOIDM@ukzn.ac.za. This article is essentially based on a paper titled 'Challenges when drafting legal aid legislation to ensure access to justice in developing countries with a small numbers of lawyers. Thinking outside the box' delivered at the International Legal Aid Group (ILAG) Access to Justice for Clients Conference, 14-16 June 2017, Johannesburg, South Africa. 
non-lawyers such as paralegals, law students and lay persons, as well as traditional mechanisms of dispute resolution to provide legal aid. In order to provide access to justice for all and safeguard the rule of law the organised legal profession, legislative drafters and legislators need to 'think outside the box' when trying to provide access to justice in an environment where there are very few lawyers. A failure to establish an accessible, effective, sustainable and credible legal aid scheme may result in civil strife and even insurrection by disaffected communities.

Key words: legal aid; developing countries; few lawyers; non-lawyer assistance; dispute resolution; traditional mechanisms

\section{Introduction}

In this article I provide a brief background to my involvement in drafting legal aid legislation for developing countries that have few lawyers and face other challenges. This is particularly true for Africa with large populations in rural areas. For instance, in 13 African countries it is estimated that rural populations constitute over 70 per cent of the total population. ${ }^{1}$ Thereafter, the relevant United Nations (UN) Principles and Guidelines on Access to Legal Aid in Criminal Justice Systems ${ }^{2}$ (UN Principles and Guidelines) that can be used to address the issue will be discussed. I will mention the challenges faced when trying to incorporate these principles and guidelines in legislation for developing countries that have few lawyers.

Mention will be made of some of the precursors that influenced the development of the UN Principles and Guidelines, followed by some of the most important relevant Principles and Guidelines. Thereafter the main challenges that hindered the implementation of the UN Principles and Guidelines are considered. These are (a) the 'big city syndrome' affecting the judiciary and practising lawyers; (b) the lack of confidence in traditional dispute-resolution mechanisms; (c) scepticism regarding the use of paralegals; (d) scepticism regarding the use of law students; (e) the failure to recognise the value of assistance without representation where no lawyers are available; ( $f$ ) over-bureaucratisation of the legal aid scheme; and (g) the lack of provision of the necessary resources by the state.

1 See, eg, United Nations Office on Drugs and Crime (UNODC) Access to legal aid in criminal justice systems in Africa: Survey Report (2011) 11-12. Although in Sierra Leone rural people only constitute $62 \%$ of the population, in Kenya they constitute $78 \%$, in Uganda $87 \%$ and in Malawi $81 \%$.

2 United Nations Principles and Guidelines on Access to Legal Aid in Criminal Justice Systems (2013), adopted by the United Nations General Assembly on 20 December 2012 by Resolution 67/187. 


\section{Background}

The author was one of the drafters of the Lilongwe Declaration ${ }^{3}$ which was subsequently adopted by the African Commission of Human and Peoples' Rights (African Commission) ${ }^{4}$ and the United Nations Economic and Social Council. ${ }^{5}$ The author further assisted in the drafting of the UN Principles and Guidelines, the United Nations Office of Drugs and Crime (UNODC) Early access to legal aid in criminal justice processes: A handbook for policy makers and practitioners (UNODC Early access handbook) ${ }^{6}$ and the United Nations Model Law on Legal Aid in Criminal Proceedings. ${ }^{7}$ In addition he assisted with the drafting of legal aid legislation for four developing countries (one civil law $^{8}$ and three African common law jurisdictions), ${ }^{9}$ and provided assistance in developing legal aid systems for ten more developing countries (five civil law ${ }^{10}$ and five common law (including two African) jurisdictions). ${ }^{11}$ The main experiences drawn on in this article are those arising from the drafting of legislation for Sierra Leone and Kenya, but passing reference will be made to other African and developing countries where similar obstacles were encountered.

3 Lilongwe Declaration on Accessing Legal Aid in Criminal Justice Systems in Africa (2004) adopted by 128 delegates from 26 countries (including 21 from Africa), on 24 November 2004; Penal Reform International and the Blum Legal Clinic of the North Western School of Law Access to justice in Africa and beyond: Making the rule of law a reality (2007) ix 39.

4 Adopted on 29 November 2006 by the African Commission on Human and Peoples' Rights in Resolution 100 on the Adoption of the Lilongwe Declaration on Accessing Legal Aid in the Criminal Justice System, http://www.achpr.org/ sessions/40th/resolutions/100/ (accessed 27 April 2017).

5 Adopted on 26 July 2007 by UN Economic and Social Council Resolution 2007/24 on International Cooperation for the Improvement of Access to Legal Aid in Criminal Justice Systems, particularly in Africa, which also informed the UN Principles and Guidelines (n 2).

6 UNODC Early access to legal aid in criminal justice processes: A handbook for policy makers and practitioners (2014).

7 UNODC Model Law for Legal Aid in Criminal Proceedings (2015).

8 Afghanistan.

9 Sierra Leone, Kenya and Uganda. In 2011 Sierra Leone had a population of 5 million, of which $60 \%$ were rural, and 100 lawyers with a ratio of one lawyer to every 50000 people; Kenya had a population of 37 million of which $84 \%$ were rural, and 3817 lawyers with a ratio of one lawyer to every 9693 people; and Uganda had a population of 32 million, of which $86 \%$ were rural, and 2000 lawyers with a ratio of one lawyer for every 16000 people; UNODC Handbook on improving access to legal aid in Africa (2011) 13. These figures may be compared with the ratios in developed world countries such as Spain which has 114143 lawyers for 45 million people (a ratio of 395:1); the United Kingdom, 151043 lawyers for 61 million (a ratio of 401:1); Italy, 121380 lawyers for 59 million (a ratio of 488:1); Germany, 151043 lawyers for 82 million (a ratio of 593:1); United States, 1143358 lawyers for 303 million (a ratio of 265:1); Brazil, 571360 lawyers for 186 million (a ratio of 321:1); and New Zealand, 10523 lawyers for 4 million (a ratio of 391:1), www.wiki.answers.com/Q/What_country_in_the _world_has_most_lawyers_per_capita (accessed 22 February 2012).

10 Lithuania, Kyrghyzstan, Mongolia, Moldova and Indonesia.

11 Somaliland (Somalia), Myanmar (Burma), Nigeria, Fiji and Pakistan. 
The process used for developing legal aid legislation includes stakeholders' meetings with justice stakeholders (a) to assess the legal aid needs of the country; (b) to develop a legal aid policy for the country; (c) to validate the policy at a stakeholders' workshop; (d) to develop draft legal aid legislation; and (e) to validate the draft legal aid legislation at a final stakeholders' meeting and to send the validation meeting's draft legislation to the legal drafters. Once the draft legislation is sent to the legal drafters, many of the provisions intended to provide access to legal aid in countries that have few lawyers or that have large rural populations are removed if they are not lawyer-centred

The legal drafters appeared to be under the impression that only lawyers can assist people in criminal cases and that paralegals, law students and lay persons acting as 'McKenzie friends' ${ }^{\prime 2}$ cannot play a role in providing such assistance. Sometimes this is done by the legal drafters themselves, ${ }^{13}$ but usually as a result of objections by the local bar association ${ }^{14}$ or the judiciary. ${ }^{15}$ The result is that the poor, marginalised and often rural populations in these countries continue to be deprived of access to justice and legal aid despite the recommendations of the UN Commission on Legal Empowerment of the Poor Report ${ }^{16}$ and the UN Principles and Guidelines, 17 both of which were unanimously adopted by all members of the UN.

\section{Country initiatives prior to the adoption of the UN Principles and Guidelines}

In Afghanistan in 2008, prior to the adoption of the UN Principles and Guidelines, the author and the then Deputy Minister of Justice developed a legal aid policy based on the principle that legal aid should be accessible, affordable, sustainable and credible when

12 'McKenzie friend' is a term of art used in common law jurisdictions arising from the decision in McKenzie v McKenzie [1970] 3 All ER 1034 (CA) to describe a lay person who assists an unrepresented litigant during court proceedings with the permission of the court.

13 As occurred with the Taqnin (Legal Drafting Department) in Afghanistan regarding civil legal aid.

14 As occurred in Malawi regarding the use of paralegals to defend accused persons in the previous Grade 4 magistrate's courts where the prosecutors are police officers with three months' training; the magistrates have six months' training; and the paralegals have 12 months' training - despite lawyers not appearing in such courts and magistrates being able to sentence convicted persons to one year in prison.

15 As occurred in Sierra Leone regarding the use of paralegals and traditional dispute resolution mechanisms - the President had to insist that these provisions be reinserted.

16 UN Commission on Legal Empowerment of the Poor Making the law work for everybody (2008) 42-43.

17 United Nations Principles and Guidelines Principle 10. 
drafting the Legal Aid Regulation. ${ }^{18}$ I subsequently included these principles when developing the legal aid policy and legislation for Sierra Leone in 2009, Kenya in 2010 and Uganda in 2011. ${ }^{19}$

I interpreted these principles as follows, based on my interactions with stakeholder groups in Afghanistan, Sierra Leone, Kenya and Uganda, as well as from my interactions with justice officials and lawyers from Kyrghyzstan, Mongolia, Moldova, Indonesia, Somaliland (Somalia), Myanmar (Burma), Fiji, the Solomon Islands and Nigeria, all of which are countries with considerable rural populations beyond the reach of lawyers. I ensured that these principles were included in the UN Principles and Guidelines when I was part of the group of experts responsible for drafting it.

\subsection{Accessibility}

Accessible legal aid services, in the criminal justice context, means that where it is in the interests of justice, every arrested and detained person in the country who cannot afford a lawyer must be provided with a lawyer by the state from the moment of their arrest or detention to ensure that they obtain 'a fair hearing'. Legal aid should be provided in both criminal and civil matters. Everyone who qualifies for legal aid should have access to legal advice and assistance as well as legal representation when this is required. ${ }^{20}$ In appropriate situations, minor criminal and civil cases in the formal justice system should be diverted to traditional customary law dispute resolution bodies such as chief's and headman's courts, to be resolved in accordance with the principles of fundamental human rights. ${ }^{21}$ For instance, in patriarchal traditional societies women are often discriminated against (such as inheritance). ${ }^{22}$

Accessible legal aid services must be available in the main cities as well as in the smaller towns and districts where there are courts. This is done by using legal practitioners, pupil legal practitioners, persons appointed by the court to represent accused persons in criminal cases, law students, legal assistants or paralegals employed by accredited non-governmental organisations (NGOs), or by allowing 'friends' employed by an accredited legal aid provider to assist accused persons. Accessible legal aid means that provision will have to be made for a mixed legal aid delivery scheme that covers the entire country using cooperation agreements between the national legal aid

18 Afghanistan Legal Aid Policy adopted at Afghanistan Legal Aid Stakeholders' Meeting on 14 January 2008 (compare A Smith 'International Afghanistan National Legal Aid Policy 2008' (unpublished, on file) 4-6.

19 Regrettably, although a Legal Aid Bill for Uganda was unanimously approved by stakeholders at a validation meeting in August 2011, it was never presented to Parliament.

20 Smith (n 18) 4.

21 Compare Sierra Leone Legal Aid Act, 2012 sec 14(2)(b)..

22 See, eg, N Tebbe 'Inheritance and disinheritance: African customary law and constitutional rights' (2008) 88 The Journal of Religion 466. 
body and accredited public and private legal aid providers. A matrix needs to be developed to identify which legal aid services are available in the different cities and towns so that steps may be taken by the independent national legal aid body to fill any gaps. ${ }^{23}$

\subsection{Affordability}

Affordable legal aid services means making the best use of available legal aid resources in the country, as previously mentioned, including public defenders and pupil public defenders; private legal practitioners and pupil legal practitioners; persons appointed by the court to represent accused persons in criminal cases; law students; or legal assistants or paralegals employed by NGOs accredited by the national legal aid body; or allowing 'friends' employed by an accredited legal aid provider to assist accused persons. The rights and duties of all these relevant legal aid providers should be specified in legal aid legislation. ${ }^{24}$

Members of the national legal aid body should be paid a 'sitting allowance' but should not be paid a salary for their membership. Employees of the national legal aid body should be remunerated in accordance with salary scales established by the national legal aid body and approved by the Ministry of Finance. ${ }^{25}$

\subsection{Sustainability}

In countries dependent on donor funding for their legal aid schemes, providing sustainable legal aid services means that mechanisms must be put in place to ensure that in the long term the provisions of the country's constitution and their international legal aid obligations will still be implemented through state funding when donor funding is no longer available. International experience ${ }^{26}$ demonstrates that for a sustainable legal aid service, the cost of complying with the constitutional and international legal aid obligations of the state must be borne by the treasury through a special allocation of funding by Parliament. Such allocation must be 'ring-fenced' to ensure that the

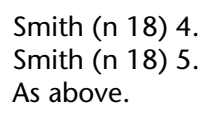

Eg, probably the two best-resourced and independent legal aid schemes in the developing world are in Fiji and South Africa, both of which receive a budget specifically allocated to them by Parliament. Fiji spends approximately US $\$ 2,5$ per capita (Fiji Ministry of Finance Economic and fiscal update: Supplement to the 2016 Budget Address (2015) 41) and South Africa about US \$1,7 per capita on legal aid (from 2016-2017 Legal Aid South Africa received an allocation of R1,2 billion for about 55 million people or about R22 (or about US \$1,7) per capita: Legal Aid South Africa Integrated Annual Report 2016-2017 (2017) 51. Most developing countries do not have independent legal aid structures and spend far less per capita on legal aid. Eg, in 2007 when South Africa spent US \$2 per capita, the spending per capita by some other African countries were Ghana, US \$0,03; Kenya, US \$0,03; Malawi, US \$0,015; Nigeria, US \$0,01; and Rwanda, US \$0,05: UNODC (n 1) 19. 
funds cannot be used for other purposes (for instance, to balance the budget of the Ministry of Justice). ${ }^{27}$

Given the current financial state of the economies of many African and developing countries it is necessary for a mixed model to be used in which donors initially assist the state to fund both criminal and civil legal aid. However, some monetary and structural support is to be provided by the state from the inception of the national legal aid scheme (for instance, the provision of office accommodation in stateowned buildings). Provision must be made for the planned phasing in of state funding to enable the government of the day to meet its constitutional and international obligations to eventually fund legal aid on its own. ${ }^{28}$

\subsection{Credibility}

A credible legal aid service means that the legal aid system is not perceived to be an organ of state. The legal aid legislation should provide for the establishment of an independent statutory legal aid body, the powers and duties of which are clearly specified in the legislation. ${ }^{29}$ A credible legal aid service also means that legal aid services provided by the independent legal aid body, as well as those provided by other public and private sector legal aid providers should be coordinated, monitored for quality and regulated by an independent statutory legal aid body. The national legal aid body should have a majority of members who are independent of government and should have the power to elect a neutral chairperson. The criteria for who qualifies for legal aid should ensure that poor, vulnerable and marginalised people have access to legal aid and should be included in legal aid legislation or its regulations. It should be widely publicised. ${ }^{30}$

These principles in one form or another have been included in the UN Principles and Guidelines.

27 As above.

28 As above.

29 In transitional countries that are moving away from authoritarian regimes there is often a reluctance to allow an independent body to run the legal aid scheme with the result that such schemes often remain under the control of the Ministry of Justice or an equivalent department. This has happened, eg, in Afghanistan and Myanmar (Burma). Initially it also happened in the Republic of Georgia during which period there was not a single acquittal in criminal cases defended by legal aid lawyers. This may change because there is now an independent body responsible for legal aid; Open Society Justice Initiative 'New Legal Aid Law in Georgia' (2007) Open Society Foundations.org/press-releases/new-legal-aid-lawadopted-georgia (accessed 6 May 2017).

Smith (n 18) 5-6. 


\section{UN Principles and Guidelines on Access to Legal Aid in Criminal Justice Systems}

The UN Principles and Guidelines state that legal aid is a fundamental right that should be provided for in national legislation and constitutions. ${ }^{31}$ The Principles and Guidelines also state that legal aid providers should be independent of state interference ${ }^{32}$ and that legal aid should be accessible, effective, sustainable and credible. ${ }^{33}$ In the UN Principles and Guidelines the word 'effective' was used instead of the term 'affordable'. The author used the term 'affordable' for the policies in Afghanistan, Sierra Leone, Kenya and Uganda. ${ }^{34}$ The legal experts drafting the UN Principles and Guidelines were of the view that for legal aid to be 'effective', it should be 'affordable'. Legal aid schemes should use legal aid bodies in both the public and private sectors and include qualified lawyers, aspiring lawyers, law students and paralegals. ${ }^{35}$ The UNODC has produced the Early access handbook $^{36}$ to assist states when implementing the UN Principles and Guidelines.

Based on personal experience, the Early access handbook is intended to deal mainly with the challenges to accessibility of legal aid in criminal justice systems in African and developing countries that have few lawyers, as this seems to be where legal drafters and legislators fail to consider the use that can be made of non-lawyers in assisting indigent people in rural areas, or the urban poor in areas where no lawyers are available to assist them.

\section{Challenges to implementing the UN Principles and Guidelines on Access to Justice}

\subsection{Challenge 1: 'Big city syndrome' affecting the judiciary and practising lawyers}

Principle 10 of the UN Principles and Guidelines state: ${ }^{37}$

States should also ensure that there is legal aid for persons living in rural, remote and economically and socially disadvantaged areas and to persons who are members of economically and socially disadvantaged groups.

31 UN Principles and Guidelines Principle 1.

32 UN Principles and Guidelines Principles 2 and 12.

33 UN Principles and Guidelines Principle 2.

34 UN Principles and Guidelines Principle 2 para 3.

35 UN Principles and Guidelines Principle 14.

36 UNODC Early access handbook (n 6).

37 UN Principles and Guidelines Principle 10. 
Principle 14 states: ${ }^{38}$

States should, in accordance with their national law and where appropriate, recognise the role played by paralegals or similar service providers in providing legal aid services where access to lawyers is limited.

However, the judiciary and lawyers in African and developing countries often view the provision of legal aid as if they were practising in a 'big city' such as a foreign capital (for instance, London or Paris) rather than in a resource-starved environment without enough lawyers and with large rural and socially-disadvantaged populations. ${ }^{39}$ Despite the majority of lawyers being concentrated in capital cities, ${ }^{40}$ the legal profession usually opposes attempts to allow paralegals to represent indigent people or assist in court in rural or socially-disadvantaged areas even when there are no lawyers available. ${ }^{41}$ Such opposition applies to paralegals acting in 'paralegal' criminal courts (for instance, where a judicial officer has a six-month diploma; a police officer prosecutor has a three-month diploma; and paralegals have a one-year diploma that might include trial advocacy, and no lawyers practise in the courts concerned). ${ }^{42}$ The judiciary and practising lawyers also seem to oppose the incorporation of traditional dispute resolution mechanisms into legal aid to divert petty crimes even where such practices are made to conform to a constitutional bill of rights. 43

Therefore, the following provisions based on the English 'McKenzie

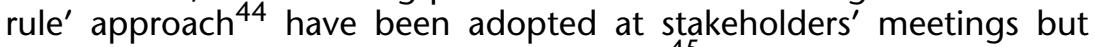
rejected by legal drafters and/or legislators: ${ }^{45}$

In towns, especially in rural areas, where there are no lawyers and where lawyers will not go, the court has the discretion to allow paralegals, law students and lay advisers to assist - but not represent - litigants and accused persons.

Where an unrepresented accused person - even if he or she is assisted by a paralegal, law student or lay adviser - is sentenced to a term of imprisonment, the record of the case goes on automatic review to a

38 UN Principles and Guidelines Principle 14.

39 UN Principles and Guidelines Principle 14 para 2.

$40 \mathrm{Eg}$, in Sierra Leone in 2009, 98 out of 100 lawyers were located in the capital city of Freetown.

41 UN Principles and Guidelines Principle 14 para 2 and fn 14 regarding the attitude of lawyers in Malawi.

42 As above.

43 See fnn $14 \& 15$.

44 McKenzie v McKenzie (n 12).

45 Sierra Leone Draft Legal Aid Bill $2009 \mathrm{sec}$ 16. The Kenya Draft Legal Aid Bill 2010 sec 37 (c) referred to such persons as 'intermediaries', but when the final Legal Aid Act, 2016 was passed, no mention was made of this provision. A similar clause was also included in the Uganda Draft Legal Aid Bill $2011 \mathrm{sec} 37$ that was validated by all stakeholders, but a Legal Aid Act was never passed by Parliament. 
High Court judge in chambers for him or her to certify that the trial, verdict and sentence were in accordance with justice. ${ }^{46}$

Linked to the above was the provision that it is a criminal offence for a paralegal, law student or lay adviser to charge a fee. ${ }^{47}$

Such clauses should be considered by law makers in situations where no lawyers are available as they are consistent with the UN Principles and Guidelines. ${ }^{48}$

\subsection{Challenge 2: Lack of confidence in traditional dispute resolution mechanisms consistent with human rights}

The UN Commission on Legal Empowerment of the Poor recognises the value and importance of traditional dispute resolution mechanisms ${ }^{49}$ and states: ${ }^{50}$

[T]o improve the state justice systems, reformers should seek out opportunities for strategic interventions that improve the operation of informal or customary justice systems and facilitate the efficient integration of the formal and informal systems.

The judiciary and legal profession, however, often are opposed to any attempts to incorporate traditional alternative dispute-resolution mechanisms into legal aid schemes - even when such mechanisms can only be used if they are consistent with fundamental human rights. ${ }^{51}$ The result is that wrongdoers in rural communities are likely to be brought before the criminal courts for minor crimes that could be settled expeditiously through traditional mechanisms involving restorative justice. This lack of confidence in traditional dispute resolution mechanisms means that justice is delayed and the courts may become clogged up with unnecessary minor criminal cases. ${ }^{52}$

46 This was not accepted at the validation meetings in Sierra Leone and Kenya, but was validated by all stakeholders for the Uganda Draft Legal Aid Bill 2011 sec 38 although, as mentioned previously, the Bill was never presented to Parliament.

47 Sierra Leone Draft Legal Aid Bill 2009 secs 16(2) and (3); Kenya Draft Legal Aid Bill $2010 \mathrm{sec} 37 \mathrm{~b}$ for paralegals and sec 37c for intermediaries. A similar clause was also included in the Uganda Draft Legal Aid Bill 2011 secs 37(2) and (3) that was validated by all stakeholders.

48 UN Principles and Guidelines Principle 10; Guideline 14.

$49 \mathrm{Eg}$, the Commission points out that 'in sub-Saharan Africa, customary land tenure law covers roughly 75 per cent of land and in some countries, such as Mozambique and Ghana, over 90 per cent of land transactions are governed by customary law', and that in Afghanistan '[t]raditional decision-making assemblies are estimated to account for more than 80 per cent of cases settled throughout Afghanistan' (UN Commission on Legal Empowerment of the Poor (n 16) 42).

50 UN Commission on Legal Empowerment of the Poor (n 16) 42-43.

51 This occurred in Sierra Leone and Kenya. In Sierra Leone the clause was reinstated in the final Legal Aid Act, $2012 \mathrm{sec}$ 14(2) at the request of the President.

52 Mongolia has a formal alternate dispute resolution system based on restorative justice whereby minor crimes are diverted from the courts after a mediated meeting between the prosecutor, the victim and the perpetrator of the crime has taken place. Thus, art 25(1) of the Criminal Procedure Law of Mongolia, 2002 provides: 'If victims of minor crimes provided for by the Criminal Law of Mongolia reconciles with the accused or defendant, the case shall be terminated.' 
For example, if a rural person steals a chicken, it is better for this matter to be diverted from the formal court system and left to a traditional dispute-resolution mechanism whereby the perpetrator, for instance, could pay compensation of two chickens instead of facing formal court charges for theft. Although the procedure is not enshrined in legislation in Malawi, the Paralegal Advisory Service Institute (PASI) has trained community-based paralegals to advise traditional leaders when cases should be diverted from traditional dispute-resolution mechanisms to the formal justice system. Conversely, they also advise the courts when minor offences could be dealt with using traditional dispute resolution systems. ${ }^{53}$

The following provisions have been adopted at stakeholders' meetings but rejected by legal drafters and/or legislators: 54

Where an accused person is charged with a minor offence, communitybased paralegals may assist the prosecutor to divert the case to a traditional dispute resolution mechanism - provided that it is consistent with fundamental human rights.

The converse of this would be that where it is not in the public interest for an accused person to be brought before a traditional tribunal, community-based paralegals may assist the traditional presiding officer to divert the case to the formal criminal justice system.

Such clauses should be considered by law makers as they are consistent with some of the issues raised in the UN Commission on Legal Empowerment of the Poor Report. 55

\subsection{Challenge 3: Scepticism regarding the use of paralegals}

The UN Principles and Guidelines emphasise the importance of paralegals in providing access to justice and state the following: ${ }^{56}$

States should recognise and encourage the contribution of lawyers' associations, universities, civil society and other groups and institutions in providing legal aid. ${ }^{5}$

States should, in consultation with civil society and justice agencies and professional associations, introduce measures -

(a) to develop, where appropriate, a nationwide scheme of paralegal services with standardised training curricula and accreditation schemes, including appropriate screening and vetting;

53 Paralegal Advisory Service Institute 'Village Mediation Programme' www.pasimalawi.org/vmp.html (accessed 28 April 2017).

54 This provision was included in the Sierra Leone Draft Legal Aid Bill $2009 \mathrm{sec} 33$ (3), but rejected after consultations with the judiciary. As mentioned in $\mathrm{n} \mathrm{51}$, it was then reinstated at the request of the President in the final Sierra Leone Legal Aid sec 14(2). A similar clause was also included in the Uganda Draft Legal Aid Bill $2011 \mathrm{sec}$ 36, but the Bill was never passed by Parliament.

55 UN Commission on Legal Empowerment of the Poor (n 16) 42-43.

56 UN Principles and Guidelines Guideline 14 para 68.

57 UN Principles and Guidelines Principle 14. 
(b) to ensure that quality standards for paralegal services are set and that paralegals receive adequate training and operate under the supervision of qualified lawyers;

(c) to ensure the availability of monitoring and evaluation mechanisms to guarantee the quality of the services provided by paralegals;

(d) to promote, in consultation with civil society and justice agencies, the development of a code of conduct that is binding for all paralegals working in the criminal justice system;

(e) to specify the types of legal services that can be provided by paralegals and the types of services that must be provided exclusively by lawyers, unless such determination is within the competence of the courts or bar associations;

(f) to ensure access for accredited paralegals who are assigned to provide legal aid to police stations and prisons, facilities of detention or pre-trial detention centres, and so forth;

(g) to allow, in accordance with national law and regulations, court accredited and duly trained paralegals to participate in court proceedings and advise the accused when there are no lawyers available to do so.

As mentioned previously, 58 the judiciary and legal profession in African and developing countries resist the idea of paralegals representing accused persons in simple criminal trials. This applies to paralegals acting in 'paralegal' low-level criminal courts where lawyers do not practise. Lawyers never represent clients in these low-level courts even though the 'paralegal' judicial officer may sentence an accused to imprisonment. ${ }^{59}$

There is less resistance to paralegals assisting with the preliminary stages of legal advice and assistance, and liaising with the police and prisons, and this sometimes needs to be spelt out in legislation to ensure compliance. Thus, the Kenyan Legal Aid Act allows paralegals to give assistance and advice. ${ }^{60}$

While provisions regarding the role of paralegals and their being formally incorporated into national legal aid schemes (subject to accreditation by such schemes) have been adopted at stakeholders' meetings and by some legislative drafters, the following provisions have been rejected by legal drafters and/or legislators: ${ }^{61}$

In small towns where there are no legal aid offices paralegals or legal assistants are stationed at every court to assist court officials in ensuring that access to justice is available by providing legal advice and assistance or referring persons to legal aid providers.

\footnotetext{
58 UN Principles and Guidelines Guideline 14 para 2.

59 See n 14.

60 Kenya Legal Aid Act 2016 sec 68(1).

61 Uganda Draft Legal Aid Bill 2011 secs 35 and 46(4) which was validated by all stakeholders but never presented to Parliament. Compare the Kenya Draft Legal Aid Bill $2010 \mathrm{sec} 65$ which provided that every ward of every county should have a 'justice advice centre'.
} 
Such clauses should be considered by law makers as they are consistent with the UN Principles and Guidelines. ${ }^{62}$

\subsection{Challenge 4: Scepticism regarding the use of law clinic students in simple criminal cases}

As in the case of paralegals, ${ }^{63}$ the UN Principles and Guidelines provide that governments should cooperate with NGOs and universities $^{64}$ - especially law faculties - and encourage the establishment of law clinics and the development of student practice rules. ${ }^{65}$

Guideline 16 provides that states should, where appropriate, also take measures: 66

(a) to encourage and support the establishment of legal aid clinics in law departments within universities to promote clinical and public interest law programmes among faculty members and the student body, including in the accredited curriculum of universities;

(b) to encourage and provide incentives to law students to participate, under proper supervision and in accordance with national law or practice, in a legal aid clinic or other legal aid community scheme, as part of their academic curriculum or professional development;

(c) to develop, where they do not already exist, student practice rules that allow students to practise in the courts under the supervision of qualified lawyers or faculty staff, provided that such rules are developed in consultation with and accepted by the competent courts or bodies that regulate the practice of law before the courts;

(d) to develop, in jurisdictions requiring law students to undertake legal internships, rules for them to be allowed to practise in the courts under the supervision of qualified lawyers.

However, the judiciary and legal profession in African and developing countries often resist the idea of law clinic students under qualified supervision representing accused persons in simple criminal trials. This applies to law clinic students acting in 'paralegal' low-level criminal courts where lawyers do not practice, but where a judicial officer may sentence an accused to imprisonment. ${ }^{67}$ As in the case of paralegals, there is less resistance to law clinic students helping with the preliminary stages of legal advice and assistance, 68 but it is still advisable to define their role in legislation or subsidiary legislation in

62 UN Principles and Guidelines Introduction paras 9 \& 10; Principle 14.

63 UN Principles and Guidelines Introduction para 5.4.

64 UN Principles and Guidelines Principle 14 and Guideline 16.

65 UN Principles and Guidelines Guideline 16(b)-(d).

66 As above.

$67 \mathrm{n} 12$.

68 See, eg, Sierra Leone Legal Aid Act 2012 where 'legal aid' is defined to include 'legal advice and assistance' and the latter is defined as being the function of a 'university law clinic' (sec 1). The Kenya Legal Aid Act 2016 defines a 'legal aid

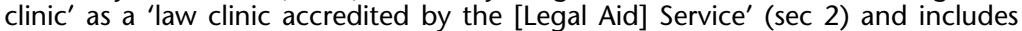
them in the definition of 'legal aid provider' (sec 2). 
order to ensure compliance. The legal profession appears to adopt a more flexible approach regarding legal representation by law graduate interns, bar course or law graduates awaiting their enrolment. ${ }^{69}$

While provisions regarding the role of law clinics and their being formally incorporated into national legal aid schemes (subject to accreditation by such schemes) have been adopted at some stakeholders' meetings and by legislative drafters, the types of provisions recommended by the UN Principles and Guidelines have not been adopted in most developing countries. Such rules should apply where no lawyers are available to assist accused persons in criminal matters and the law students are attached to law clinics and are properly supervised by a qualified legal practitioner.

If the principle of law clinic student practice is included in the principal legal aid legislation, the mechanics of its implementation can be spelt out in subsidiary legislation.

Some developing countries such as the Philippines introduced student practice rules many years ago. ${ }^{70}$ The Philippines law states: $:^{71}$

A law student who has successfully completed his 3rd year of the regular four year prescribed law curriculum and is enrolled in a recognised law school's clinical legal education programme approved by the Supreme Court, may appear without compensation in any civil, criminal or administrative case before any trial court, tribunal, board or officer, to represent indigent clients accepted by the legal clinic of the law school.

In South Africa an early attempt was made to draft student practice rules for the country in $1975,{ }^{12}$ and a modified set of the rules was drafted by the author and published in 1982. ${ }^{73}$ These rules were aimed at delimiting the area in which law students could operate, providing mechanisms for certification of students, and ensuring proper supervision. ${ }^{74}$ The rules were approved by the then Association of Law Societies and the university law deans, but were never implemented by the then apartheid government. The first Minister of Justice under South Africa's new democratic government also committed to introducing student practice rules but this never materialised. ${ }^{75}$ The reasons have not been articulated, but there seems to be less enthusiasm for such rules after an undergraduate four-year LLB was introduced in place of the previous five-year LLB

69 Sierra Leone Legal Aid Act sec 1; compare Kenya Legal Aid Act 2016 sec 2.

70 See Rules of Civil Procedure (1997) Rule 138-A.

71 As above.

72 See P Ellum Legal aid developments in South Africa July 1973-June 1975 (1975) 64-65; compare DJ McQuoid-Mason 'Student practice rules' in DJ McQuoidMason (ed) Legal aid and law clinics in South Africa (1985) 137138.

73 See DJ McQuoid-Mason An outline of legal aid in South Africa (1982) 194-197.

74 McQuoid-Mason (n 72) 139.

75 See, eg, the proposed South African Student Practice rules in DJ McQuoid-Mason 'Whatever happened to the Proposed South African Student Practice Rules?' (2008) 41 De Jure 580. 
programme, although the five-year LLB degree is still offered by several universities. While it was suggested that student practice could be included in such programmes, ${ }^{76}$ on reflection there is no reason in principle why it should not include students in the four-year programmes, provided that the students are properly trained and supervised.

In African and developing countries where law graduates are sufficiently mature and properly supervised, such clauses should be considered by law makers as they are consistent with the UN Principles and Guidelines. ${ }^{77}$

\subsection{Challenge 5: Failure to recognise the value of assistance without representation where lawyers are not available}

The UN Principles and Guidelines provide that (a) legal aid should be provided for people living in rural and remote areas; ${ }^{78}$ (b) states should encourage widespread partnerships in dealing with legal aid; ${ }^{79}$ and (c) states should recognise the role played by paralegals or similar service providers. 80

Principle 10 states:

33 States should also ensure that legal aid is provided to persons living in rural, remote and economically and socially disadvantaged areas and to persons who are members of economically and socially disadvantaged groups.

Principle 14 states:

40 Where appropriate, public-private and other forms of partnership should be established to extend the reach of legal aid.

Guideline 13 states:

65 Where there is a shortage of qualified lawyers, the provision of legal aid services may also include non- lawyers or paralegals.

Guideline 14 states:

67 States should, in accordance with their national law and where appropriate, recognise the role played by paralegals or similar service providers in providing legal aid services where access to lawyers is limited.

There is resistance in African and developing countries to allowing paralegals, law students or lay advisers to assist an indigent litigant or accused person in court as a 'McKenzie friend' ${ }^{81}$ when no lawyers are available. ${ }^{82}$ The suggestion is that the court may allow such persons

See generally McQuoid-Mason (n 75). See Annexure A.

UN Principles and Guidelines Guideline 16.

UN Principles and Guidelines Principle 10.

UN Principles and Guidelines Principle 14.

UN Principles and Guidelines Guidelines $13 \& 14$.

$81 \mathrm{n} 12$. 
or litigants to be advised and assisted by a paralegal, law student or lay adviser who may not represent the accused person or litigant but may assist the accused before and during trial. ${ }^{83}$ This provision would apply to unsupervised paralegals, law students or lay advisers, for instance, in deep rural areas.

Decisions by the court in such unrepresented cases that resulted in imprisonment could go on automatic review to a High Court judge in chambers, as is the practice in South Africa for unrepresented accused subjected to certain periods of imprisonment. ${ }^{84}$ Some countries prohibit anyone except qualified lawyers from giving legal advice and assistance - a clear contradiction of the UN Principles and Guidelines. ${ }^{85}$

The following provisions have been adopted at stakeholders' meetings but rejected by most legal drafters and/or legislators:

1 Before the trial a paralegal, law student or lay adviser may:

advise and assist litigants regarding civil claims and accused persons on all preliminary matters including bail applications, pleading to charges and such other matters. ${ }^{86}$

2 During the trial a paralegal, law student or lay adviser may:

(a) take notes and quietly advise and assist the accused person or litigant in such a manner as not to disturb the proceedings;

(b) suggest questions that the accused person or litigant might ask in examination in chief, cross-examination or re-examination;

(c) assist the accused person or litigant to make opening or closing statements and in the case of an accused person who is convicted a plea in mitigation. ${ }^{8}$

In Afghanistan, prior to the formation of the Independent Bar Association of Afghanistan, in terms of the Interim Criminal Code for Courts (Interim Criminal Code), ${ }^{88}$ the courts used to have the

82 McKenzie v McKenzie (n 12).

83 McKenzie v McKenzie (n 12) para 5.2.

84 The South African Criminal Procedure Act 51 of 1977 provides that where an unrepresented accused is (a) sentenced to a term of imprisonment without the option of a fine for a period of three months or more by a magistrate of less than seven years' standing; or (b) sentenced to a term of imprisonment without the option of a fine for a period of six months or more by a magistrate of more than seven years' standing, the conviction and sentence must be automatically reviewed by a High Court judge (sec 302).

85 UN Principles and Guidelines Introduction paras 9 \& 10; Guideline 14.

86 Uganda Legal Aid Bill, $2011 \mathrm{sec}$ 37(1)(a); compare Sierra Leone Legal Aid Act, $2010 \mathrm{sec}$ 16(1)(a) and Kenya Legal Aid Bill, $2010 \mathrm{sec} 37$ (c) which allowed an 'intermediary' to assist unrepresented persons, but this was not incorporated into the Kenya Legal Aid Act of 2016.

87 Uganda Legal Aid Bill, $2011 \mathrm{sec}$ 37(1)(ii); compare Sierra Leone Legal Aid Act, $2010 \mathrm{sec}$ 16(1)(b)-(e); Sierra Leone Legal Aid Act, $2010 \mathrm{sec}$ 16(1)(a); Kenya Legal Aid Bill, $2010 \mathrm{sec} 37$ (c) which allowed an 'intermediary' to assist unrepresented persons, but this was not included in the Kenya Legal Aid Act of 2016. Interim Criminal Code for Courts, 2004. 
discretion to appoint 'an educated person with knowledge of the law' to represent criminal accused.

Article 96 of the Afghanistan Interim Criminal Code provided for 'interim defence counsel' in the following circumstances:

1 Up to when in the country there will be not available a sufficient number of defence counsels, as established in article 18, the suspect or the accused can have recourse to the assistance of an educated person having some knowledge of legal issues (sic).

2 To this end the President of each Court shall institute a list of persons having the qualities indicated in the previous paragraph following the indications from the Capital of the Ministry of Justice and for Districts and Provincial Courts of Government Cases Department (sic).

To ensure that people who live in remote areas where there are courts but no lawyers, are assisted during criminal trials, legal aid legislation should contain provisions that allow paralegals, law students or lay persons to assist them as this is consistent with the flexible approach to legal aid in criminal matters recommended by the UN Principles and Guidelines. ${ }^{89}$

\subsection{Challenge 6: Over-bureaucratisation of the legal aid scheme}

Principles 3, 7 and 9 of the UN Principles and Guidelines provide that (a) legal aid should be provided without a means test where the interests of justice so require; (b) states should ensure effective legal aid; and (c) states should provide safeguards if legal aid is delayed: 90

Principle 3 states:

21 Legal aid should also be provided, regardless of the person's means, if the interests of justice so require, for example, given the urgency or complexity of the case or the severity of the potential penalty.

Principle 7 states:

27 States should ensure that effective legal aid is provided promptly at all stages of the criminal justice process.

28 Effective legal aid includes, but is not limited to, unhindered access to legal aid providers for detained persons, confidentiality of communications, access to case files and adequate time and facilities to prepare their defence.

Principle 9 states:

31 States should establish effective remedies and safeguards that apply if access to legal aid is undermined, delayed or denied or if persons have not been adequately informed of their right to legal aid.

There is a tendency in countries where earlier legal aid schemes have been administered by the courts or by government officials for there to be excessive documentation requirements when applying for legal

89 UN Principles and Guidelines Principles $10 \& 14$; Guidelines $13 \& 14$.

90 UN Principles and Guidelines Principles 3, $7 \& 9$. 
aid. Legal aid applicants sometimes have to obtain certificates from a number of government officials in order to substantiate that they are unemployed or indigent, instead of simply completing a form and attaching a salary slip or making a sworn declaration that they are unemployed. ${ }^{91}$

Appeal procedures may also be cumbersome, requiring legal aid applicants who are refused legal aid to apply to an appeals committee, instead of the next highest legal aid officer. ${ }^{92}$ Some countries prefer the national legal aid scheme to be run as part of the Ministry of Justice and subject to its bureaucracy, both of which undermine its credibility and accessibility. ${ }^{93}$

The following provisions have been adopted at stakeholders' meetings and are often accepted by most legal drafters and/or legislators for inclusion in the principal Act or subsidiary legislation:

(a) Applicants need only complete one form disclosing their income and assets and liabilities backed by supporting documentation where it exists (eg, a salary slip, or income and expenditure statement from self-employed persons). ${ }^{9}$

(b) In the case of unemployed persons they make a sworn statement to the effect that they have made attempts to find work but remain unemployed.

(c) If a person knowingly makes a false statement on his or her application form the person may be prosecuted.

(d) Emergency legal aid is provided in urgent cases for persons who appear to be indigent without a formal application for legal aid being made at the time. ${ }^{-5}$

Such clauses should be included in legal aid legislation and regulations of countries in order to bring their legal aid systems into line with the UN Principles and Guidelines. ${ }^{96}$

91 This happened in many of the Eastern and Central European and Central Asian countries before their legal aid systems were reformed.

$92 \mathrm{Eg}$, the Sierra Leone Legal Aid Act, 2012 requires appeals against the Board's decision to refuse legal aid to be made to an 'Appeals Panel' consisting of a Judge of Appeal as Chairperson, the Chief Social Welfare Officer 'or his representative not below the rank of Deputy Secretary', a retired public officer nominated by the Public Service Commission and two representatives of civil society organisations accredited to provide legal aid, one of whom shall be a woman (sec 28(2)).

93 As, eg, in Afghanistan because there was mutual mistrust between the Ministry of Justice NGOs and the Republic of Georgia when its legal aid scheme was first established as a division in the Ministry of Justice but was supposedly insulated from interference by the Ministry in its daily operations. The Georgia legal aid scheme is now completely independent of the Ministry.

94 These provisions are usually mentioned in the subsidiary legislation such as Ministerial regulations or a legal aid guide (compare Legal Aid South Africa Legal aid guide (2014) 269.

95 Sierra Leone Legal Aid Act $2012 \sec 29$.

96 UN Principles and Guidelines Principles 3, $7 \& 9$. 


\subsection{Challenge 7: Lack of provision of necessary resources by the state}

The UN Principles and Guidelines provide that states should provide the necessary human and financial resources for a nationwide legal aid scheme. ${ }^{97}$

Principle 2 states that 'states should allocate the necessary human and financial resources to the legal aid system' ${ }^{98}$ Guideline 12 adds that

states should, where appropriate, make adequate and specific budget provisions for legal aid services that are commensurate with their needs, including by providing dedicated and sustainable funding mechanisms for the national legal aid system. ${ }^{99}$

Guideline 12 also suggests that states could take the following measures: 100

(a) to establish a legal aid fund to finance legal aid schemes, including public defender schemes, to support legal aid provision by legal or bar associations; to support university law clinics; and to sponsor non-governmental organisations and other organisations, including paralegal organisations, in providing legal aid services throughout the country, especially in rural and economically and socially disadvantaged areas;

(b) to identify fiscal mechanisms for channelling funds to legal aid, such as:

(i) allocating a percentage of the State's criminal justice budget to legal aid services that are commensurate with the needs of effective legal aid provision;

(ii) using funds recovered from criminal activities through seizures or fines to cover legal aid for victims;

(c) to identify and put in place incentives for lawyers to work in rural areas and economically and socially disadvantaged areas (eg tax exemptions or reductions, student loan payment reductions);

(d) to ensure fair and proportional distribution of funds between prosecution and legal aid agencies.

Guideline 12 also states: ${ }^{101}$

The budget for legal aid should cover the full range of services to be provided to persons detained, arrested or imprisoned, suspected or accused of, or charged with a criminal offence, and to victims. Adequate special funding should be dedicated to defence expenses such as expenses for copying relevant files and documents and collection of evidence, expenses related to expert witnesses, forensic experts and social workers, and travel expenses. Payments should be timely.

97 UN Principles and Guidelines Principle 2 and Guideline 12.

98 UN Principles and Guidelines Principle 2 para 15.

99 UN Principles and Guidelines Guideline 12 para 60.

100 UN Principles and Guidelines Guideline 12 para 61.

101 UN Principles and Guidelines Guideline 12 para 62. 
Governments often profess to support a legal aid system but are reluctant to provide sufficient resources - either in money or in kind. It is useful to give such governments examples of the per capita expenditure on legal aid in different countries so that they may establish a suitable benchmark. ${ }^{102}$ Another useful guideline is to compare the amount spent on the prosecution service with that provided for legal aid: There should be some degree of parity to ensure equality of arms. ${ }^{103}$ The Fiji Legal Aid Commission's statefunded budget is 80 per cent that of the Directorate of Public Prosecutions - excluding the budget for police prosecutors who are used outside the main towns. ${ }^{104}$

The state should not expect to run a legal aid scheme solely on pro bono services by lawyers, ${ }^{105}$ although this may be a useful adjunct to a national legal aid scheme.

Guideline 11 encourages pro bono legal aid work by lawyers: ${ }^{106}$

States should also take measures:

(a) to encourage legal and bar associations to support the provision of legal aid by offering a range of services, including those that are free (pro bono), in line with their professional calling and ethical duty;

(b) to identify incentives for lawyers to work in economically and socially disadvantaged areas (eg, tax exemption, fellowships and travel and subsistence allowances);

(c) to encourage lawyers to organise regular circuits of lawyers around the country to provide legal aid to those in need.

While provisions stating that funding for legal aid must be specifically appropriated by the treasury for that purpose have only been adopted at stakeholders' meetings and by legislative drafters, the following provisions are likely to be rejected by legislative drafters and/or legislators:

102 Eg, for the year 2010-2011 in South Africa, Parliament allocated R1,1 billion (about US \$110 million) to Legal Aid South Africa (Legal Aid South Africa Annual Report (2012) 94) or an amount of about $\$ 2,20$ per head for each member of South Africa's approximately 50 million people. This compares with the per capita expenditure during 2010 on legal aid in England and Wales of US $\$ 59(£ 39)$ and in New Zealand of US $\$ 27$ ( $£ 18)$ (Ministry of Justice (UK) International comparisons of public expenditure on legally aided services: Ad hoc statistics note (2011) 3). In 2008 England and Wales spent S \$59 (£39) per capita; Scotland US \$47 (£31); Spain and France each US $\$ 8(£ 5)$; and Portugal US $\$ 5(£ 3)$ (Ministry of Justice (UK) above 7). Fiji at US $\$ 3$ per capita (Fiji Legal Aid Commission Functional review (2016) (unpublished) $9-10$ is probably the best-funded legal aid scheme in a developing country followed by South Africa).

103 UN Principles and Guidelines Guideline 12 para 61(d).

104 Fiji Legal Aid Commission Functional Review (n 102) 9-10.

105 South Africa tried this in 1962 and failed; GW Cook 'A history of legal aid in South Africa' in Faculty of Law, University of Natal Legal aid in South Africa (1974) 31-32.

106 UN Principles and Guidelines Guideline 11 para 56. 
(a) Funding should be based on per capita expenditure for the population of the country as a whole.

(b) Funding for legal aid should be partially commensurate with the expenditure on prosecution services.

(c) Not more than about a third of the money allocated for legal aid should be spent on administrative support - the majority of funding should used for legal aid service delivery. ${ }^{109}$

(d) Incentives should be given to legal aid providers working in rural or socially disadvantaged areas (eg tax exemptions or student loan payment reductions).

Legal aid legislation and regulations in African and developing countries should include such provisions in order to make them consistent with UN Guideline 12.

\section{Conclusion}

The UN Principles and Guidelines on Access to Legal Aid in Criminal Justice Systems and the UNODC Early access handbook may be used when drafting legal aid legislation to ensure the accessibility, effectiveness, sustainability and credibility of legal aid services.

The challenges to the UN Principles and Guidelines when seeking to provide legal aid in African and developing countries that have small numbers of lawyers can be overcome by including appropriate legislative provisions that are consistent with the Principles and Guidelines.

Ensuring access to justice for all and the rule of law requires legislative drafters and legislators to consider how the needs of poor and vulnerable people in remote areas in conflict with the law, where there are no lawyers, can obtain assistance, rather than bowing to vested interests.

As paragraph 1 of the Introduction to the UN Principles and Guidelines reminds us, '[l]egal aid is an essential element of a fair, humane and efficient criminal justice system that is based on the rule of law'.

107 Compare n 96.

108 Compare text accompanying n 98.

109 This is roughly the ratio of expenditure by Legal Aid South Africa.

110 The writer is not aware of a country that includes such a provision in their legal aid legislation. 
The failure to establish an accessible, effective, sustainable and credible legal aid scheme may result in civil strife and even insurrection by disaffected communities, as occurred in Sierra Leone where the lack of access to justice was a major contributor to the outbreak of the Civil War. ${ }^{111}$

111 Personal remark made to the author by the President of Sierra Leone when he was discussing the policy for the drafting of the Legal Aid Bill for Sierra Leone in April 2009. 